\title{
Oral Acute Toxicity of Ethanolic Extract of Rhizomes from Smilax domingensis Willd. in Cuba
}

\section{Ricardo Méndez ${ }^{1}$, José González ${ }^{1 *}$, Pilar A Soledispa ${ }^{2}$, Enrique Gómez ${ }^{3}$ and Max Monan ${ }^{4}$}

${ }^{1}$ Facultad De Educación En Ciencias Técnicas, Ucp «Enrique José Varona», La Habana, Cuba

${ }^{2}$ Facultad De Ciencias Químicas, Universidad De Guayaquil, Ecuador

${ }^{3}$ Instituto De Farmacia y Alimentos, Universidad De La Habana, Cuba

${ }^{4}$ Arvarnam, Rosiers, Quartier Thoraille, Rivière-Salée, Martinica

*Corresponding Author: José González, Facultad De Educación En Ciencias Técnicas, Ucp "Enrique José Varona", La Habana, Cuba.
Received: October 18, 2021

Published: December 09, 2021

(C) All rights are reserved by José González., et al.

\begin{abstract}
Smilax domingensis Willd. (Smilacaceae), also known as raíz de China and zarzaparrilla de la Tierra (Cuba), is a tropical American climbing shrub. The rhizome is widely used in medicine in manifold pharmacological activities. An evaluation was realized to determine the oral acute toxicity from an ethanolic extract of rhizomes of this spice that grows in Cuba in 25 CD1 female rats using a dosage in $2000,300,50,5 \mathrm{mg} / \mathrm{kg}$. for 14 days, were evaluating the weight, feeding and the presence/absence of toxic symptoms, according to The Commission of European Communities (ECDO). Histopathological results in liver and kidneys revealed that at $2000 \mathrm{mg} / \mathrm{Kg}$ was observed necrosis, hyperplasia in Kupffer cells and glomerular hypertrophy. At 300, 50 and $5 \mathrm{mg} / \mathrm{Kg}$ were detected inflammation on hepatocytes by edema and dilatation on renal tubules. No mortality was produced at different dosage used in the experiments (2000, 300,50 and $5 \mathrm{mg} / \mathrm{Kg}$ ), however, histopathological analysis evidenced that on hepatic and renal tissues were causing alterations.
\end{abstract}

Keywords: Smilax Domingensis; Oral Acute Toxicity; Histopathological Analysis; Kupffer’s Cells; Glomerular Hypertrophy

\section{Introduction}

Smilax gender is one of the largest inside Smilacaceae family, principally locate in tropical America and Caribbean countries and have around 200 species of flourishing climbing plants, many of them, are woody and with thorn. In our country, there are some species, among them, Smilax domingensis, known as bejuco zarzaparrilla [1].

The rhizome is voluminous and reddish brown in color. Is use in decoction and infusion and the population attribute it antihyper- tensive properties [2] (Figure 1). Smilacaceae is a family of around three genders and 230 species, the most notable of which is Smilax, which has close to 250 species globally and is found in Mesoamerica with 26 species $[3,4]$.

The plant belongs to Plantae Kingdom, Magnoliophyte Division, Liliopside Class, Liliales Order, Smilacaceae Family, Smilax Gender and Specie Smilax domingensis [5]. There have been few anatomic investigations of American Smilax, notably for species from Argentina [6] and Brazil [7]. 


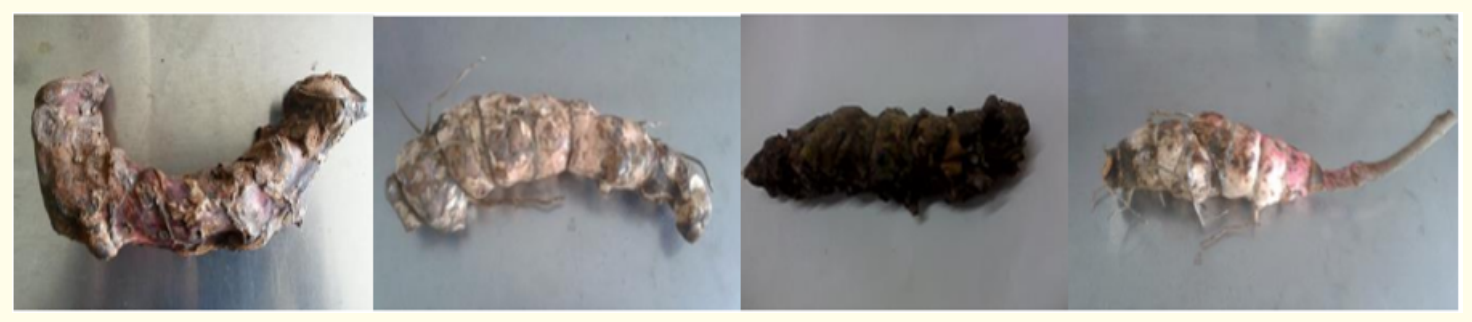

Figure 1: Rhizomes from S. domingensis Willd. in Cuba.
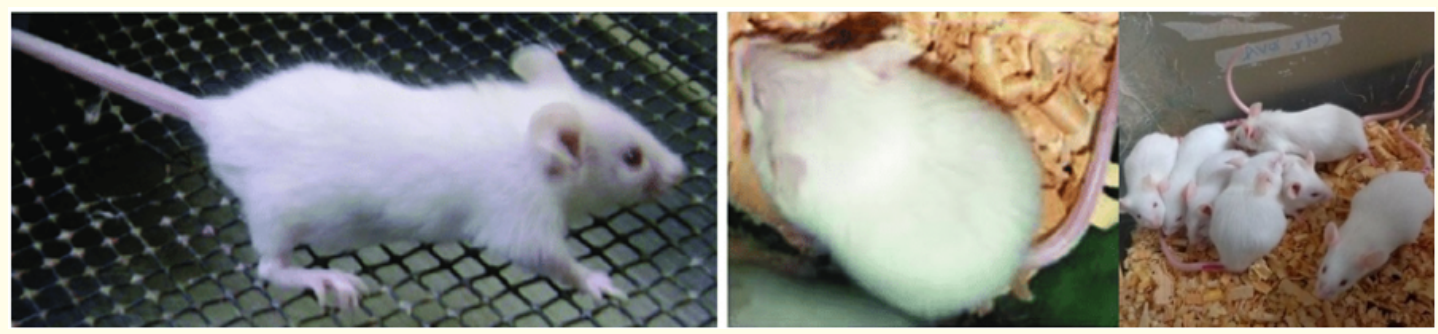

Figure 2: CD1 line female rats used in the experiments.

In the scientific literature, there are some data on phytochemical components. The steroidal saponins, phytosterols, and triterpenoids are the major components found and shared by most members of the genus [8]. Pharmaceutical forms include infusion, tincture, elixir, lotion, and micro pulverized powder [9].

The physicochemical properties of crude medicine are all under WHO parameters. Phytochemical screening revealed the presence of alkaloids, oils and/or fats, coumarins, saponins, flavonoids, pyrogallol-type tannins, quinones, catechins, reductants, sugars, triterpens, and steroids, but not resins, amino acids, cardiotonic glycosides, anthocyanidins, and astringent and/or bitter principles [10].

Using a Shimadzu GCMS-QP2010 Ultra, a preliminary chemical analysis of the principal components of an ethanolic extract with dried rhizomes allowed the characterization of organic acids, reductants sugars, lactones and related substances. The chemical matches were almost 80\% like the NIST21 and NIST107 libraries [11]. Alkaloids, antraquinones, flavonoids, catechins, tannins or phenolic compounds, saponins, triterpenes, or steroids are not present on the sample, for that reason the chemical composition of the rhizome from $S$. domingensis in our country differs from the rhizome that grow in Guatemala [12].

The purpose of this study was to investigate the oral acute toxicity of an ethanolic extract from rhizomes of $S$. domingensis in experimental animals.

\section{Materials and Methods}

Plant material and reagents

The rhizome was collected in March 2016 from Sierra Cristal, Sagua de Tánamo, Holguín Province, Cuba. The voucher number HAJB 089193 was issued by the National Botany Garden in Havana, Cuba. Dr. Jorge E. Gutiérrez Amaro validated the plant material. The gathered rhizomes were dried in the shade at room temperature (temperature $30^{\circ} \mathrm{C}-40^{\circ} \mathrm{C}$ ) on the Research Lab Table at Havana University's Faculty of Pharmacy and Foods, pulverised into powdered form (1 mm), and kept in airtight containers.

The extracts were made from the pulverized material $(60 \mathrm{~g})$ without a screen in a Soxhlet apparatus for 20 hours in $675 \mathrm{~mL}$ of 95 percent ethanol. The ethanolic extracts were concentrated and 
evaporated to $200 \mathrm{~mL}$ under vacuum at $120 \mathrm{rpm}, 70{ }^{\circ} \mathrm{C}$, and 500 mbar. All the reagents used were of the analytical grade (Merck). Prior to use in an ultrasonic bath without filtration, all solvents were degassed.

\section{Oral acute toxicity}

The acute toxicity test was measured according to the method of Commission of the European Communities № 423, 1996 [13]. Twenty-five female rats belonging to CD1 line with an average weight of 20-25g were divided into 5 different groups (5 animals per group) (Figure 2). The extract was administrated at a dosage of 2000, 300, 50 and $5 \mathrm{mg} / \mathrm{Kg}$ (four groups) and one, with water as control group. During the test were evaluated the weight of the animals, the feeding, and the presence/absence of toxic symptoms according to the rules of The Commission of European Communities (ECDO). At the end of the test the animals were sacrificed using diethyl ether and autopsied. The organs (lungs, hearts, kidneys, stomachs, etc.) were extracted and observed if they are affected. If some of the organs were affected were taken samples for the histopathological analyses. The weight of the animals was processed statistically to register the mean and standard deviation.

\section{Results and Discussion}

Determination of Oral Acute Toxicity of ethanolic extract from

\section{S. domingensis}

Oral acute toxicity of ethanolic extracts of rhizomes from $S$. domingensis demonstrated that the extract classified as non-toxic according to the classification system of the Commission of the European Communities. Ethanolic extract belongs to class $\mathrm{CTA}_{0}$ in which the Mortality $>2000$. No animal die during the period of the research. During the three first hours at $2000 \mathrm{mg} / \mathrm{Kg}$ doses post administration, 2 from 5 animals showed soft excrements and 3 from 5 manifested grooming. No acute toxicity was demonstrated $\left(\mathrm{DL}_{50} 300,50\right.$ and $\left.5 \mathrm{mg} / \mathrm{Kg}\right)$.

Livers and kidneys were taken to histopathological studies, observing that at $2000 \mathrm{mg} / \mathrm{Kg}$ were produced necrosis, hyperplasia of Kupffer cells and glomerular hypertrophy. At dosage of 300, 50 and $5 \mathrm{mg} / \mathrm{Kg}$ were observed inflammation of hepatocytes by edema and dilatation of the renal tubules.

It could be proven that to the worked doses of 2000, 300, 50 and $5 \mathrm{mg} / \mathrm{kg}$, mortality was not presented; however, the histopatholog- ical analysis evidenced alteration in the hepatic and renal tissues to the different studied doses.

Our results were different with those found with Cáceres., et al. 2012, where they showed that using an extract in 20\% Tween 80 $(200,250,300,350$ and $400 \mathrm{mg} / \mathrm{kg}$ ) administered at five groups of five mice (20-23g) by orogastric cannula. Animal behavior was observed at 1, 4, 8, 12, 24, 48 during eight days. No acute toxicity was demonstrated $\left(\mathrm{DL}_{50} 400 \mathrm{mg} / \mathrm{kg}\right)$.

\section{Conclusion}

OAT (oral acute toxicity) of ethanolic extract of rhizomes from $S$. domingensis Willd. in Cuba was tested in 2000, 300, 50 and $5 \mathrm{mg} /$ $\mathrm{kg}$ for the first time, showing that no animals used in the experiments die, but at $2000 \mathrm{mg} / \mathrm{Kg}$ were observed necrosis in livers and kidneys, hyperplasia on Kupffer cells and glomerular hypertrophy. At dosage of 300, 50 and $5 \mathrm{mg} / \mathrm{Kg}$ were observed inflammation of hepatocytes by edema and dilatation of the renal tubules. By these reasons, authors recommended the use of this medicinal part of that plant carefully and after the exhaustive research to get a better information about the recommended dosage. Others extractive methods will be implemented to obtain another kind of pharmaceutic extracts to enrich our medication arsenal and give to this medicinal organ the effective use in the traditional medicine.

\section{Bibliography}

1. Roig JT. "Plantas Medicinales Aromáticas y Venenosas de Cuba”. Editorial Científico Técnica, La Habana (2014): 671-672.

2. Ferrufino L and Gómez-Laurito J. "Estudio Morfológico de Smilax L. (Smilacaceae) en Costa Rica, con Implicaciones Sistemáticas". Lankesteriana 4 (2004): 5-36.

3. Huft MJ., et al. "Flora Mesoamericana". Universidad Nacional Autónoma de México, México, Missouri Botanical Garden by the National History Museum, London (1994): 20-25.

4. "British Herbal Pharmacopoeia Bournemouth". The British Herbal Medicine Association (1983): 197-198.

5. Standley PC and Steyermark JA. "Flora of Guatemala". Fieldiana. Botany 24 (1952): 92-100.

6. Guaglianone ER and Gattuso S. "Estudios taxonómicos sobre el género Smilax (Smilacaceae)". Boletín de la Sociedad Argentina de Botánica 27 (1991): 105-129. 
7. Andreata RHP. "Revisão das espécies brasileiras do genero Smilax Linnaeus (Smilacaceae)". Pesquisas em Botânica 47 (1997): 1-243.

8. Bérdy J., et al. "CRC Handbook of Antibiotic Compounds". Boca Raton, CRC Press 7.2 (1982): 255.

9. Cáceres A. "Vademécum Nacional de Plantas Medicinales". Guatemala, Editorial Universitaria, USAC (2009): 247-248.

10. Yaque JG., et al. "Pharmacognostic and Phytochemical Studies of Smilax domingensis Willd. in Cuba". American Journal of Plant Sciences 8 (2017): 1462-1470.

11. Soledispa PA., et al. "GC-MS Chemical Characterization of Main Components of Smilax domingensis Wild. in Cuba". Journal of Agricultural Studies 6.2 (2018): 79-86.

12. Cáceres A., et al. "Ethnobotanical, Pharmacognostical, Pharmacological and Phytochemical Studies on Smilax domingensis in Guatemala". Revista Brasileira de Farmacognosia 22 (2012): 239-248.

13. "Commission of the European Communities". Journal of European Communities 35 (1996): 110-112.

\section{Assets from publication with us}

- Prompt Acknowledgement after receiving the article

- Thorough Double blinded peer review

- Rapid Publication

- Issue of Publication Certificate

- High visibility of your Published work

Website: www.actascientific.com/

Submit Article: www.actascientific.com/submission.php

Email us: editor@actascientific.com

Contact us: +919182824667 